\title{
Strictly aerobic and anaerobic bacteria associated with sinking particulate matter and zooplankton fecal pellets
}

\author{
Micheline Bianchi ${ }^{1}$, Danielle Marty ${ }^{1}$, Jean-Louis Teyssié ${ }^{2}$, Scott W. Fowler ${ }^{2}$ \\ ${ }^{1}$ Microbiologie Marine, CNRS UPR 223, Campus de Luminy Case 907, F-13288 Marseilles Cedex 9, France \\ ${ }^{2}$ IAEA Marine Environment Laboratory, BP 800, MC-98012 Monaco Cedex
}

\begin{abstract}
Particulate material collected in sediment traps at $80 \mathrm{~m}$ depth in coastal northwestern Mediterranean waters, and fresh fecal pellets of copepods harvested in the surrounding water, were examined for the presence and activity of ammonia-oxidizing and methanogenic bacteria. Results provide the first evidence for the coexistence of living and active cells of methanogenic and nitrifying bacteria in either fresh zooplankton fecal pellets or large settling particles containing numerous large size fecal pellets. In addition, the presence of these 2 bacterial types in both copepods and the fecal pellets produced by them suggests that the bacteria probably originate from the digestive tract of zooplankton, most likely as ingested species for nitrifiers and enteric species for methanogens.
\end{abstract}

\section{INTRODUCTION}

Particulate material in ambient seawater provides microenvironments in which the different chemical characteristics allow the occurrence of microbial processes that would otherwise be impossible to achieve on the particle surface or in the surrounding water (Tranvik \& Sieburth 1989). In addition, in these consortia of trophic-specific bacteria embedded within the same particle, the diverse bacterial groups may interact functionally, one supplying the other with nutrients (Hobbie \& Fletcher 1988).

The vertical distribution of nitrifying bacteria and their metabolic activity in the oceanic water column have been shown to be associated with particles (Karl et al. 1984). The suspended particle layer often coincides with the base of the photic zone and the nitrite maximum (Spinrad et al. 1989). This layer (between 50 and $150 \mathrm{~m}$ ) also exhibits a 30 to $70 \%$ supersaturated $\mathrm{CH}_{4}$ concentration relative to atmospheric equilibrium (Lamontagne et al. 1973, Rudd \& Taylor 1980). Deeper oceanic waters are generally undersaturated, indicating an in situ biological production of methane (Scranton \& Brewer 1977, Sieburth 1987). Methaneproducing bacteria, which are obligate anaerobes, do not exist in a free state in the oxygenated water column, but could survive if associated with reducing microenvironments such as suspended particles, fecal pellets or digestive tracts of marine organisms (Oremland 1979, Burke et al. 1983)

The co-occurrence of ammonia-oxidation and methane-production activities in particulate material would furnish evidence for microniches of opposite redox potential allowing association between ammonia oxidizers and methanogens. A number of marine species of ammonia oxidizers (reviewed by Bedard \& Knowles 1989) are able to oxidize simultaneously methane and ammonia, and at the measured open ocean concentrations, i.e. nanomolar range, ammonia oxidizers could use methane as a carbon source (Ward 1990).

In order to test this hypothesis, we measured nitrification and methane production in particulate material collected from the coastal waters off Monaco (1) with sediment traps at a depth of $80 \mathrm{~m}$ in a water column of $200 \mathrm{~m}$ deep, and (2) with fresh fecal pellets of copepods harvested in the surrounding water. The goal of this initial experiment was not to measure precise quantitative rates of nitrification or methane production in the different particle types, but to demonstrate the simul- 
taneous occurrence and activities of these 2 bacterial groups in particulate materials collected in the water column

\section{MATERIALS AND METHODS}

Sediment trap samples. Unpoisoned sediment traps were moored from 22 to 25 January 1991 at a site approximately 3 nautical miles off the coast of Monaco. The traps, a cylindrical design with $H / D=2.5$ and a collecting area of $0.078 \mathrm{~m}^{2}$ (Fowler et al. 1991), were moored at $80 \mathrm{~m}$ depth in water column approximately $200 \mathrm{~m}$ deep. At the end of the 3 d collection period, the contents in the collection cup were placed in an ice chest and transported to the laboratory within. $2 \mathrm{~h}$ of trap retrieval.

At the laboratory, 1 aliquot of the bulk sample was immediately removed for the microbial experiments. Other aliquots were taken to determine mass flux, $\mathrm{C}$ and $N$ content and the numerical flux of different types of zooplankton fecal pellets (for technical details, see Heussner et al. 1987, Fowler et al. 1991, Peinert et al. 1991)

Zooplankton fecal pellets. During the recovery cruise, zooplankton were collected by making several horizontal plankton tows (333 $\mu \mathrm{m}$ mesh nets) at approximately $5 \mathrm{~m}$ depth at the trap site. The zooplankton, principally mixed copepod species, were sequentially sieved through 2000, 1000 and $500 \mu \mathrm{m}$ mesh netting to remove larger species and detritus, and the fraction retained on $500 \mu \mathrm{m}$ mesh placed in large shipboard fecal pellet collectors (La Rosa 1976) for return to the laboratory. The copepods were allowed to defecate in the collectors for $4 \mathrm{~h}$, after which time 2 fractions of fecal pellets $(<150 \mu \mathrm{m}$ and $>43 \mu \mathrm{m},<43 \mu \mathrm{m}$ and $>10 \mu \mathrm{m})$ were carefully removed from the nets at the bottom of the collector system. These pellets and the copepods that produced them were immediately used in the microbial assays.

Nitrifying activity. Nitrification was determined by measuring the nitrite concentration in flasks containing inhibitors (Perfettini \& Bianchi 1990). Briefly, in flasks of $50 \mathrm{ml}$ final volume, (1) the natural nitrifying activity was determined by the increase of nitrite in flasks without addition of substrate $\left(\mathrm{NH}_{4}\right)_{;}$(2) the potential nitrifying activity was demonstrated by the increase of nitrite in duplicates receiving $50 \mu \mathrm{M}$ final concentration of $\mathrm{NH}_{4} \mathrm{Cl}$. The nitrite concentration corresponded to the increase due to ammonia oxidation minus the decrease due to nitrite oxidation. (3) In duplicates with the same concentration of $\mathrm{NH}_{4} \mathrm{Cl}, 10 \mathrm{mM}$ $\mathrm{NaClO}_{3}$ (final concentration) was added to inhibit nitrite oxidation (Belser \& Mays 1980). This nitrite concentration was only due to ammonia oxidation. The difference between the nitrite value in the flasks with $\mathrm{NaClO}_{3}$ and the flasks receiving only $\mathrm{NH}_{4} \mathrm{Cl}$ corresponded to the quantity of nitrite disappearing by possibly several processes including oxidation of nitrite to nitrate.

All flasks were incubated at $15^{\circ} \mathrm{C}$ in the dark, and nitrite concentrations were measured every $2 \mathrm{~d}$ over a period of $50 \mathrm{~d}$. Nitrification rates ( $\mu$ mol nitrite produced $\mathrm{l}^{-1} \mathrm{~d}^{-1}$ ) were calculated during the exponential phase of nitrite increase.

For material collected with the sediment trap, $2.2 \mathrm{ml}$ of the seawater slurry containing particles were used as an inoculum for activity measurements and were transferred into $50 \mathrm{ml}$ (final volume) of $0.2 \mu \mathrm{m}$ filtered seawater from the same site.

Following incubation to collect copepod fecal pellets, the remaining individuals with voided guts were added to $15 \mathrm{ml}$ of seawater $(<43 \mu \mathrm{m})$. Of this water, $3 \mathrm{ml}$ were used as an inoculum for activity measurements. Fecal pellets were collected on a $150 \mu \mathrm{m}$ filter, the water drained off and the pellets resuspended in $40 \mathrm{ml}$ of filtered seawater $(<0.2 \mu \mathrm{m})$. Of this suspension $2 \mathrm{ml}$ were then used as an inoculum. The same protocol was followed for the fecal pellets collected on $43 \mu \mathrm{m}$ filters

Methanogenic activity. All experiments were carried out following the methodology of Hungate (1969) modified for sample collection and manipulation in the field and laboratory. The production of methane ( $\mu \mathrm{mol}$ $\mathrm{l}^{-1} \mathrm{~d}^{-1}$ ) was assessed by quantifying the increase of methane in the headspace of tubes containing particulate samples under anoxic conditions with or without carbon amendments. Methane in the headspace of the culture tubes was determined every 2 d during a $40 \mathrm{~d}$ incubation period using a Girdel Gas Chromatograph (Series 30) equipped with a Chromosorb G AWDMCS column and a flame ionization detector. Argon was used as the carrier gas, and temperatures of column, injector, and detector were set at 80,190 , and $220^{\circ} \mathrm{C}$ respectively (Marty et al. 1990).

Eight tubes were inoculated for each particulate sample. A sample of $3 \mathrm{ml}$ of the solution containing particles were transferred into 8 tubes supplied with oxygen-free gas $\left(\mathrm{H}_{2} 100 \%\right)$. The natural production of methane (production from in situ organic material) was assessed by quantifying methane production in the headspace of 4 tubes (2 tubes incubated at $15^{\circ} \mathrm{C}$ and 2 at $30^{\circ} \mathrm{C}$ ) without any amendment. The potential methane production was measured in the 4 remaining tubes which received a pool of methanogenic substrates [formate $\left\{2.5 \mathrm{~g} \mathrm{l}^{-1}\right.$, final concentration $\}+$ acetate $\left(2.0 \mathrm{~g} \mathrm{I}^{-1}\right)+$ methanol $\left(2.5 \mathrm{~g} \mathrm{l}^{-1}\right)+$ trimethylamine $(2.5 \mathrm{~g}$ $\mathrm{I}^{-1} \mathrm{l}$ and were incubated at 15 and $30^{\circ} \mathrm{C}$ in the dark.

For each sample of particulate material collecled with sediment traps, $5 \mathrm{ml}$ of the particle slurry 
were used as inoculum for 8 anaerobic tubes. The natural and potential production of methane were then measured at 15 and $30^{\circ} \mathrm{C}$ using the previously described protocol.

After incubation for fecal pellet production, the 'empty' copepods were added to $15 \mathrm{ml}$ of seawater $(<43 \mu \mathrm{m})$ and $3 \mathrm{ml}$ of this suspension were transferred into 8 anaerobic tubes. The pellets collected on the 43 and $150 \mu \mathrm{m}$ filters were resuspended separately in $40 \mathrm{ml}$ of seawater $(<0.2 \mu \mathrm{m})$, and $3 \mathrm{ml}$ of this suspension were also transferred into 8 anaerobic tubes.

\section{RESULTS}

\section{Sediment trap particles}

The characteristics of the sedimenting particulate material collected off Monaco during that period are presented in Table 1 . Both mass flux (ca $0.5 \mathrm{~g} \mathrm{~m}^{-2} \mathrm{~d}^{-1}$ ) and fecal pellet flux $\left(2.6 \times 10^{4}\right.$ pellets $\left.\mathrm{m}^{-2} \mathrm{~d}^{-1}\right)$ were at

Table 1 Characteristics of particulate material collected in sediment trap located at $80 \mathrm{~m}, 3$ miles off Monaco, 22 to 25 January 1991

\begin{tabular}{|c|c|c|c|}
\hline \multicolumn{2}{|c|}{ Sample parameter } & \multicolumn{2}{|c|}{ Measured value } \\
\hline \multirow{2}{*}{\multicolumn{2}{|c|}{$\begin{array}{l}\text { Total particle dry weight } \\
\text { Mass flux. }\end{array}$}} & \multicolumn{2}{|c|}{$115.5 \mathrm{mg}$} \\
\hline & & \multicolumn{2}{|c|}{$494 \mathrm{mg} \mathrm{m}^{-2} \mathrm{~d}^{-1}$} \\
\hline \multicolumn{2}{|c|}{ Total C content } & \multicolumn{2}{|c|}{$6.61 \pm 0.01 \%$} \\
\hline \multicolumn{2}{|c|}{ Organic C content } & \multicolumn{2}{|c|}{$4.17 \pm 0.01 \%$} \\
\hline \multicolumn{2}{|c|}{ Total N content } & \multicolumn{2}{|c|}{$0.50 \pm 0.01 \%$} \\
\hline \multicolumn{2}{|c|}{ Fecal pellet flux } & \multicolumn{2}{|c|}{$2.62 \times 10^{4}$ pellets $\mathrm{m}^{-2} \mathrm{~d}^{-1}$} \\
\hline \multicolumn{2}{|c|}{ Total pellet no. } & \multicolumn{2}{|c|}{6120 pellets } \\
\hline Pellet type & \multicolumn{2}{|c|}{$\begin{array}{l}\text { Fraction of total pellets } \\
\qquad(\%)\end{array}$} & $\begin{array}{l}\text { Mean volume } \\
\qquad\left(\mu \mathrm{m}^{3}\right)\end{array}$ \\
\hline Elliptical I & & 65.3 & $4.28 \times 10^{7}$ \\
\hline Elliptical II & & 1.31 & $4.05 \times 10^{6}$ \\
\hline Elliptical III & & 5.23 & $9.00 \times 10^{7}$ \\
\hline Cylindrical & & 13.71 & $2.78 \times 10^{7}$ \\
\hline Spherical & & 9.81 & $9.08 \times 10^{6}$ \\
\hline Salp-like flakes & & 3.93 & Not measured \\
\hline Amorphous & & 0.65 & Not measured \\
\hline \multicolumn{4}{|c|}{ Fecal mass contribution to total mass ${ }^{a}$} \\
\hline \multicolumn{4}{|c|}{${ }^{a}$ Calculations based on formula: } \\
\hline \multicolumn{4}{|c|}{ Fecal pellet dry weight $=$} \\
\hline \multicolumn{4}{|c|}{$\begin{array}{c}\text { (mean pellet volume for each type) } \times \text { (fecal pellet density) } \\
\times \text { (number of each fecal pellet type) }\end{array}$} \\
\hline \multicolumn{4}{|c|}{ (fecal pellet wet weight)/(fecal pellet dry weight) } \\
\hline \multicolumn{4}{|c|}{$\begin{array}{l}\text { where fecal density is } 1.22 \mathrm{~g} \mu \mathrm{m}^{-3} \times 10^{-12} \text { (Komar et al. } \\
\text { 1981), fecal pellet wet weight } / \mathrm{dry} \text { weight }=4.4 \\
\text { (Fowler 1977) }\end{array}$} \\
\hline
\end{tabular}

the low end of the range of values that have been recorded in winter months at this station (Teyssié et al. 1990, Fowler et al. 1991). Nevertheless, the relatively high fraction (55\%) of the particle mass represented by fecal pellets is typical for coastal waters in this region (ibid.). Approximately $70 \%$ of the pellets were elliptical and of the type normally produced by copepods suggesting that these zooplankton species were the major contributors to the fecal pellet flux at that time.

\section{Nitrifying activity}

The particulate material collected in the trap at $80 \mathrm{~m}$ depth demonstrated the highest natural nitrification rate (Table 2). The addition of ammonium as substrate increased more than 10 times the natural nitrifying activity. When nitrite oxidation was inhibited in the presence of $\mathrm{ClO}_{3}$, the measured ammonia oxidation rate was similar to the potential rate value, demonstrating the absence of nitrite oxidation. Normalized to the weight of particulate material, oxidation rates were 0.42 and $5.84 \mu \mathrm{mol} \mathrm{g}^{-1} \mathrm{~d}^{-1}$ ammonia oxidized during natural and potential nitrification, respectively. As we were not able to separate the different kinds of particles (especially fecal pellets) in the trap sample, it was not possible to determine whether or not this activity was related to a specific particle type. From the potential ammonia oxidation, and using a coefficient of $0.7 \mathrm{pmol} \mathrm{cell}^{-1} \mathrm{~d}^{-1}$ (Ward et al. 1982), we were able to estimate the presence of $7.9 \times 10^{3}$ cells $\mathrm{g}^{-1}$ ammonia oxidizers.

During the same experiment, samples were also collected at $40 \mathrm{~m}$ depth by means of miniaturized sediment traps. This particulate material exhibited a strong potential activity (up to $38 \mu \mathrm{mol}$ nitrite produced $\mathrm{l}^{-1}$ particle slurry $\mathrm{d}^{-1}$ ) with a nitrite oxidation rate which was about half the ammonia oxidation rate. These results demonstrated the simultaneous presence of both ammonia and nitrite oxidizers in these particles. Unfortunately, detailed characteristics of the particulate material were not determined in this 'mini'-trap, however, visually the sample appeared to be similar to that obtained at $80 \mathrm{~m}$.

In incubations with dead animals, the flasks exhibited a growth of heterotrophic bacteria as demonstrated by the turbidity of the water. Ammonium was probably produced from the decaying organic material, and hence the natural nitrifying activity was not negligible $(0.55 \mu \mathrm{mol} \text { nitrite produced }]^{-1}$ copepod suspension $\mathrm{d}^{-1}$ ). Potential rates of nitrification in the copepods were low and no nitrite oxidation was detected.

Fecal pellets, which ranged in size from 43 to $150 \mu \mathrm{m}$, showed high rates for all activities tested. In particular, the nitrite oxidation rate $\left(8.70 \mu \mathrm{mol}^{-1}\right.$ fecal 
Table 2. Nitrifying activity expressed as increase or decrease in nitrite concentration ( $\mu$ mol of $\mathrm{NO}_{2}$ produced or consumed)

\begin{tabular}{|c|c|c|c|c|}
\hline Sample & $\begin{array}{c}\text { (A) } \\
\text { Natural } \\
\text { nitrification }\end{array}$ & $\begin{array}{c}\text { (B) } \\
\text { Potential } \\
\text { nitrification }\end{array}$ & $\begin{array}{c}(\mathrm{C}) \\
\text { Potential } \\
\text { ammonia oxidation }\end{array}$ & $\begin{array}{c}\text { (D) } \\
\text { Potential } \\
\text { nitrite oxidation }\end{array}$ \\
\hline \multicolumn{5}{|l|}{ Sediment trap particles } \\
\hline$\mu \mathrm{mol} \mathrm{l} l^{-1}$ particle slurry $\mathrm{d}^{-1}$ & 1.36 & 19.04 & 17.91 & 0 \\
\hline$\mu \mathrm{mol} \mathrm{g}{ }^{-1}$ dry weight $\mathrm{d}^{-1}$ & 0.42 & 5.84 & 5.50 & 0 \\
\hline \multicolumn{5}{|l|}{ Copepods } \\
\hline$\mu \mathrm{mol} 1^{-1}$ of copepod suspension $\mathrm{d}^{-1}$ & 0.55 & $0.32(1 / 2)$ & $0.27(1 / 2)$ & 0 \\
\hline \multicolumn{5}{|l|}{ Fecal pellets } \\
\hline$<150 \mu \mathrm{m}$ and $>43 \mu \mathrm{m}$ & 1.05 & 1.07 & 9.77 & 8.70 \\
\hline$<43 \mu \mathrm{m}$ and $>10 \mu \mathrm{m}$ & 0.12 & 0.10 & 0.12 & 0.02 \\
\hline \multicolumn{5}{|c|}{$\begin{array}{l}\text { (A) No substrate added; (B) } 50 \mu \mathrm{M} \mathrm{NH} \mathrm{NH}_{4} \mathrm{Cl} \text { added; (C) nitrite oxidation inhibited: } 50 \mu \mathrm{M} \mathrm{NH} \mathrm{N}_{4} \mathrm{Cl}+10 \mathrm{mM} \mathrm{NaClO}_{3} \text { added; } \\
\text { (D) calculated as: rate (C) - rate (B) }\end{array}$} \\
\hline \multicolumn{5}{|l|}{ (1/2): Only 1 duplicate positive } \\
\hline
\end{tabular}

pellet suspension $\mathrm{d}^{-1}$ ) was similar to the ammonia oxidation rate $\left(9.77 \mu \mathrm{mol} \mathrm{l}^{-1}\right.$ suspension $\left.\mathrm{d}^{-1}\right)$. It should be noted that during similar experiments performed with copepod fecal pellets harvested in the Gulf of Marseilles, ammonia oxidation activity was detectable within the first $5 \mathrm{~d}$ of incubation (unpubl.). Table 2 also shows that the natural activity $\left(1.05 \mu \mathrm{mol} \mathrm{l}^{-1}\right.$ fecal pellet suspension $\mathrm{d}^{-1}$ ) was identical to the potential activity $\left(1.07 \mu \mathrm{mol} \mathrm{l}^{-1}\right.$ suspension $\left.\mathrm{d}^{-1}\right)$. The fecal pellets contained both ammonia and nitrite oxidizers which performed the 2 steps of nitrification at the same time and at the same rate. This activity, compared with the absence of activity in 'empty' animals, underscores the important role of gut microflora in copepods (and probably other zooplanktonic animals) in controlling the biogeochemical cycles of elements such as nitrogen through the permanent inoculation of the water column by specialized bacterial populations.
Fecal pellets in the smaller size class (10 to $43 \mu \mathrm{m}$ ) exhibited very low nitrifying activity, ranging between 0.10 and $0.12 \mu \mathrm{mol}$ nitrite produced $1^{-1}$ fecal pellet suspension $\mathrm{d}^{-1}$. Nitrite oxidation was also detected, but the rate was low $\left(0.02 \mu \mathrm{mol} \mathrm{l}^{-1}\right.$ suspension $\left.\mathrm{d}^{-1}\right)$. This size class of fecal pellets contained less material than the 43 to $150 \mu \mathrm{m}$ class, which could explain the lower activities measured.

\section{Methanogenic activity}

Table 3 compares the rates of methane production at in situ temperature $\left(15^{\circ} \mathrm{C}\right)$ and at $30^{\circ} \mathrm{C}$ in the presence and absence of exogenous substrates. It is important to note that these results do not represent in situ rates, because of the long incubation period ( $40 \mathrm{~d}$ ) required for the production of methane; however, they do indicate potential methanogenic activities.

Table 3. Methanogenic activity expressed as increase in methane concentration ( $\mu \mathrm{mol}$ of $\mathrm{CH}_{4}$ produced)

\begin{tabular}{|c|c|c|c|c|}
\hline \multirow[t]{2}{*}{ Sample } & \multicolumn{2}{|c|}{ No addition } & \multicolumn{2}{|c|}{ Substrate addition } \\
\hline & $15^{\circ} \mathrm{C}$ & $30^{\circ} \mathrm{C}$ & $15^{\circ} \mathrm{C}$ & $30^{\circ} \mathrm{C}$ \\
\hline \multicolumn{5}{|l|}{ Sediment trap particles } \\
\hline$\mu$ mol l-1 particle slurry $\mathrm{d}^{-1}$ & 0 & $41.27(1 / 2)$ & $0.10(1 / 2)$ & 0.41 \\
\hline$\mu \mathrm{mol} \mathrm{g}{ }^{-1}$ dry weight $\hat{d}^{-1}$ & 0 & 12.51 & 0.03 & 0.13 \\
\hline \multicolumn{5}{|l|}{ Copepods } \\
\hline$\mu \mathrm{mol} \mathrm{l} \mathrm{l}^{-1}$ of copepod suspension $\mathrm{d}^{-1}$ & 0 & 0.10 & 0 & 0.25 \\
\hline \multicolumn{5}{|l|}{$\begin{array}{l}\text { Fecal pellets } \\
\mu \mathrm{mol} \mathrm{l}^{-1} \text { of fecal pellet suspension } \mathrm{d}^{-1}\end{array}$} \\
\hline$<150 \mu \mathrm{m}$ and $>43 \mu \mathrm{m}$ & 0 & 0 & 0 & $219.82(1 / 2)$ \\
\hline$<43 \mu \mathrm{m}$ and $>10 \mu \mathrm{m}$ & 0 & $0.05(1 / 2)$ & 6.30 & $0.17(1 / 2)$ \\
\hline
\end{tabular}


Methane production was detected in 9 of 16 sets of duplicate samples, and for 5 of these 9 positive results, methanogenic activity was observed in only one of the duplicate tubes. Compared with unsupplemented samples incubated at in situ temperature, in which methane production was undetectable, both an increase in incubation temperature and the addition of substrates caused the expected stimulation of methanogenic activity. However, the incubation temperature and the presence of substrates have less effect on methanogenic rates than the high heterogeneity of the particulate material. Therefore, the dominant factor governing the methane production rates, both in sediment trap particulates and in copepods and their fecal pellets, appears to be the abundance and/or nature of the particles introduced into the culture tubes

The presence of active methanogenic bacteria in sediment trap particulates has been checked by additional experiments performed on particles collected at the same sampling station, with miniaturized traps, at 40 and $80 \mathrm{~m}$ depth, in which similar high methane production rates $\left[52.80\right.$ and $32.81 \mu \mathrm{mol} \mathrm{CH}_{4}$ produced $\mathrm{l}^{-1}$ particle slurry $\mathrm{d}^{-1}$, respectively) have been observed. In these 'mini'-traps, which contain a lower abundance of particulates, methanogenic activity required substrate amendment. This fact suggests that methanogenesis was limited by insufficient amounts of remineralized nutrients released from the particles

Low, but measurable rates of methane production were detected in 'empty' zooplankton samples, whereas fecal pellets exhibited higher rates (Table 3 ). Methanogenic activity associated with both copepods and egested fecal pellets is consistent with the presence of methanogens in the gut of copepods. The differences in methanogenic rates exhibited by the 2 sizefractions $(>43 \mu \mathrm{m}$ and $<43 \mu \mathrm{m}$ ) of fecal pellets may be due to the lower number of pellets in the smaller sizefraction. Similar experiments (not shown), using copepods collected off Marseilles and their fecal pellets, have confirmed both the stimulation of methane production by carbon amendment and the presence of high rates of production in fecal pellets.

\section{DISCUSSION AND CONCLUSIONS}

The results reported here provide the first evidence for the coexistence of methanogenic and nitrifying bacteria, which exhibit different and incompatible energetic metabolisms, in both fresh zooplankton fecal pellets and large settling particles. The co-occurrence of these 2 types of bacteria could result in an association between the members of this consortium: on one hand, aerobic nitrifying bacteria which interact with oxygen could contribute, with heterotrophs, to oxygendepleted microzones wherein methanogens can flourish; and on the other hand, anaerobic methanogenic bacteria would produce methane that could be used as energy and carbon sources by nitrifiers.

Conrad \& Seiler (1988) have observed that elevated methane concentrations coincided with the accumulation of decaying material. In addition, Ward (1986) noted a maximum in nitrification rates at the depth of enhanced nutrient regeneration where fresh organic matter produces ammonia. The particles we collected in a sediment trap at $80 \mathrm{~m}$ may be considered as fresh material since the $\mathrm{C} / \mathrm{N}$ ratio (8.34) was relatively low. These particulates contained numerous fecal pellets which have been reported as major zones of decomposition of biological material in the sea (Gowing \& Silver 1983). Of the fecal pellets collected at $80 \mathrm{~m}$ depth, $79 \%$ exhibited a mean volume between 2.78 and $4.28 \times 10^{7}$ $\mu \mathrm{m}^{3}$. The large size of these pellets may allow different, spatially distinct sites to occur in close physical proximity (Alldredge \& Cohen 1987), i.e. some microniches leading to the development of strict aerobes like nitrifying bacteria, and other microniches favoring the development of strict anaerobic bacteria such as methanogens. It is interesting to note that sediment trap particulates exhibited the highest rates of methane production $\left(12.51 \mu \mathrm{mol} \mathrm{g}^{-1} \mathrm{~d}^{-1}\right)$ as well as potential nitrification $\left(5.84 \mu \mathrm{mol} \mathrm{g}{ }^{-1} \mathrm{~d}^{-1}\right)$.

With regard to the presence of nitrifying and methanogenic bacteria in both copepods and the fecal pellets produced by them (present results and unpubl. data), these bacteria probably originate from the digestive tract of zooplankton and are incorporated into the fecal pellet interior at the time the pellet is being produced. The lower bacterial activities recorded in copepods, compared with those in fecal pellets, probably resulted from the gut microflora of copepods being greatly reduced after the passage of pellets (Sieburth 1991). Bacterial populations inside fecal pellets could originate as either enteric or ingested species (Gowing \& Silver 1983). Ingested species may be aerobic bacteria such as the nitrifiers, which originate from the surrounding seawater and survive gut passage as digestion resistant forms. In contrast, enteric bacteria may be anaerobic species, such as methanogens whose metabolism and growth are inhibited by even slight traces of oxygen. It should be further considered that a symbiotic relationship between zooplankton and methanogens is one possible explanation for the paradoxical production of methane in the upper ocean (Oremland 1979, Traganza et al. 1979). For example, the anaerobic gut of a zooplankter provides oxygen-depleted conditions which allow methanogenic bacteria to develop and, after being egested in the oxygenated water column, the oxygen- 
depleted microenvironment of fecal material is maintained by oxygen-consuming bacteria, such as heterotrophs and nitrifiers.

Acknowledgements The IAEA Marine Environment Laboratory operates under a bilateral agreement between the International Atomic Energy Agency and the Government of the Principality of Monaco. We thank J.-C. Miguel for the C/N analyses and the crew of the 'Physalie' (Musée Océanographique) for their assistance with the sample collection.

\section{LITERATURE CITED}

Alldredge, A. L., Cohen, Y (1987). Can microscale chemical patches persist in the sea? Microelectrode study of marine snow, fecal pellets. Science 235: 689-691

Bedard, C., Knowles, R. (1989). Physiology, biochemistry and specific inhibitors of $\mathrm{CH}_{4}, \mathrm{NH}_{4}^{+}$, and $\mathrm{CO}$ oxidation by methanotrophs and nitrifiers. Microbiol. Rev. 53: 68-84

Belser, L. W., Mays, E. L. (1980). Specific inhibition of nitrite oxidation by chlorate and its use in assessing nitrification in soils and sediments. Appl, environ. Microbiol. 39: $505-510$

Burke, R. A. Jr, Reid, D. F, Brooks, J. M., Lavoie, D. M. (1983). Upper water column methane geochemistry in the eastern tropical North Pacific. Limnol. Oceanogr. 28: 19-32

Conrad, R., Seiler, W. (1988). Methane and hydrogen in seawater (Atlantic Ocean). Deep Sea Res. 35: 1903-1917

Fowler, S. W. (1977). Trace elements in zooplankton particulate products. Nature 269: 51-63

Fowler, S. W., Small, L. F., La Rosa, J. (1991). Seasonal particulate carbon flux in the coastal northwestern Mediterranean Sea, and the role of zooplankton fecal matter. Oceanol. Acta 14: 77-85

Gowing, M. M., Silver, M. W. (1983). Origins and microenvironments of bacteria mediating fecal pellet decomposition in the sea. Mar. Biol. 73: 7-16

Heussner, S., Monaco, A., Fowler, S. W. (1987). Characterization and vertical transport of settling biogenic particles in the northwestern Mediterranean. In: Degans, E. T., Izdar, E., Honjo, S. (eds.) Particle flux in the ocean. Mitt. Geol. - Palaont. Inst. Univ Hamburg, SCOPE/UNEP Sonderband 62: 127-147

Hobbie, J. E., Fletcher, M. M. (1988). The aquatic environment. In: Linch, J. M., Hobbie, J. E. (eds.) Microorganisms in action: concepts and applications in microbial ecology, Part 3: Micro-organisms in their natural environments. Blackwell Scientific Publications, Oxford, p. $132-162$

Hungate, R. E. (1969). A roll tube method for cultivation of strict anderobes. In: Norris, J. R., Ribbons, D. W (eds.) Methods in microbiology, Vol. 3B. Academic Press, New York, p. 117-132

Karl, D. M., Knauer, G. A., Martin, J. H., Ward, B. B. (1984). Bacterial chemolithotrophy in the ocean is associated with sinking particles. Nature 309: 54-56

Lamontagne, R. A., Swinnerton, J. W., Linnenbom, V. J., Smith, W. D. (1973). Methane concentration in various marine environments. J. geophys. Res. 78: $5317-5324$

Komar, P. D., Morse, A. P., Small, L. F., Fowler, S. W. (1981). An analysis of sinking rates of natural copepod and euphausiid fecal pellets. Limnol. Oceanogr. 24: 172-180
La Rosa, J. (1976). A simple system for recovering zooplank tonic faecal pellets in quantity. Deep Sea Res. 23: 995-997

Marty, D., Esnault, G., Caumette, P., RanaivosonRambelarisoa, E., Bertrand, J. C. (1990). Dénitrufication, sulfato-réduction et méthanogénèse dans les sédiments superficiels d'un étany saumâtre méditerranéen. Oceanol. Acta 13: 199-210

Oremland, R. S. (1979). Methanogenic activity in plankton samples and fish intestines: a mechanism for in situ methanogenesis in oceanic surface waters. Limnol. Oceanogr. 24: 1136-1141

Peinert, R. D., Fowler, S. W., La Rosa, J., Miguel, J.-C., Teyssié, J.-L. (1991). Vertical flux and microplankton assemblages in the Gulf of Lions during spring 1990. In: Martin, J.-M., Barth, H. (eds.) EROS 2000. Third workshop on the North-west Mediterranean Sea. Water Pollution Research Reports, CEC, Brussels, p. 413-424

Perfettini, J., Bianchi, M. (1990). The comparison of two simple protocols designed to initiate and stimulate ammonia oxidation in closed aquaculture systems. Aquaculture 88: $179-188$

Rudd, J. W., Taylor, C. D. (1980). Methane cycling in aquatic environments. In: Droop, M. R., Jannasch, H. W. (eds.) Advances in aquatic microbiology. Academic Press, London, p. 77-150

Scranton, M. I., Brewer, P. G. (1977). Occurrence of methane in near surface waters of western subtropical north Atlantic. Deep Sea Res. 24: 127-138

Sieburth, J. McN. (1987). Contrary habitats for redox-specific processes: methanogenesis in oxic waters and oxidation in anoxic waters. In: Sleigh, M. A. (ed.) Microbes in the sea. Ellis Horwood Series in Marine Sciences, Chichester, p. $11-38$

Sieburth, J McN. (1991). Methane and hydrogen sulfide in the pycnocline: a result of tight coupling of photosynthesis and 'benthic' processes in stratified waters. In: Rogers, J. E., Whitman, W. B. (eds.) Microbial production and consumption of greenhouse gases: methane, nitrogen oxides, and halomethanes. American Society for Microbiology, Washington, D.C., p. 147-174

Spinrad, R. W., Glover, H., Ward, B. B., Codispoti, L. A., Kullenberg, G. (1989). Suspended particle and bacteria maxima in Peruvian coastal waters during a cold water anomaly. Deep Sea Res. 36: 715-733

Teyssié, J.-L., Miguel, J.-C., Nolan, C. V. (1990). Seasonal changes in mass flux and fecal pellet sedimentation at Monaco. Rapp. Comm. int. Mer. Médit. 32: 280

Traganza, E. D., Swinnerton, J. W., Cheek, C. H. (1979). Methane supersaturation and ATP-zooplankton blooms in near-surface waters of the Western Mediterranean and the subtropical North Atlantic Ocean. Deep Sea Res. 26A: $1237-1245$

Tranvik, L. J., Sioburth, J. MCN. (1989). Effects of flocculated humic matter on free and attached pelagic microorganisms. Limnol. Oceanogr. 34: 688-699

Ward, B. B., Olson, R. J., Perry, M. J. (1982). Microbial nitrification rates in the primary nitrite maximum off southern California. Deep Sea Res. 29: 247-255

Ward, B. B. (1986). Vitrification in marine environments. In: Prosser, J. I. (ed.) Special publications of the Society for General Microbiology, Vol. 20, Nitrification IRL Press Oxford/Washington, D.C., p. 157-184

Ward, B. B. (1990). Kinetics of ammonia oxidation by a marine nitrifying bacterium: methane as a substrate analogue Microb. Ecol 19: 211-225

Manuscript first received: March 20, 1992

Revised version accepted: September 28, 1992 